\title{
Threading the Needle: The United States and Silicon Valley Business in a Changing China
}

\author{
Sean Randolph
}

\begin{abstract}
Successfully navigating issues due to uncertainties in US-China relations will require executives to thread a needle between the opportunity presented by China's market and a geopolitical landscape that is generating a growing range of barriers. While there policy approaches will change from Trump to Biden, many policies will remain, especially in the technology sector. Businesses believe that despite fewer legal restrictions, the issue of a level playing field will remain in China, but that this will not affect overall profitability in the Chinese market.
\end{abstract}

Keywords US-China relations will require executives to "thread a needle" • Policy approaches $\cdot$ Fewer legal restrictions $\cdot$ Level playing field

Recent years have witnessed significant changes in the economic and policy landscape in China, matched by shifts in the United States that have altered the long-term strategies of many US companies doing business there. Businesses dislike uncertainty, particularly when making decisions on long-term investment. The uncertain path forward in US-China relations therefore raises both tactical and strategic issues for China's overseas partners, including investors and technology companies in the San Francisco/Silicon Valley Bay Area. Successfully navigating those issues will require executives to thread a needle between the opportunity presented by China's market and a geopolitical landscape that is generating a growing range of barriers. Because the Bay Area is at the core of the United States' technology and innovation system and is home to a disproportionate number of its leading technology companies and tens of thousands of startups, how this pathway is navigated will be consequential for both sides.

\section{Navigating an Uncertain Policy Environment}

The barriers and uncertainties relate to both trade and investment, as well as trust.

\footnotetext{
S. Randolph ( $\otimes)$

Bay Area Council Economic Institute, San Francisco, USA

(C) The Author(s) 2022

H. Wang and L. Miao (eds.), Transition and Opportunity, China and Globalization, https://doi.org/10.1007/978-981-16-8603-0_5
} 
Turning first to trade, the US-China trade war that began in 2016 and paused in late 2019 with the Phase One trade agreement imposed escalating reciprocal tariff barriers on a broad range of both United States and Chinese products. While damage was done in China, businesses in the United States were hurt as well, particularly in agriculture and manufacturing, where American producers saw the cost of components imported from China rise. While the Phase One agreement rolled back some tariffs, most remain in place. This raises both the question of what circumstances would enable their removal, or whether they might become permanent. Significantly, although the trade war was initiated by the Trump Administration with the goal of reducing the US trade imbalance with China, it was unsuccessful in achieving that objective. As consumer demand in the United States rose during the pandemic and Chinese production recovered, US imports grew despite the tariffs and at the end of 2020 the goods deficit stood at USD 310 billion, only marginally lower than the USD 345 billion recorded in 2019 .

How the Biden Administration chooses to address those legacy tariffs will impact both costs and markets. That will start with the Phase One agreement. While some progress was made toward its goal of increasing Chinese imports by USD 200 billion above 2017 levels, the pandemic of 2020 disrupted its implementation and at the end of the year China's imports were far below the targets-meeting $82 \%$ of the target in agriculture, but only $57 \%$ for covered goods and $37 \%$ for energy. With China the only major economy to achieve positive growth in 2020, and with targets spanning a twoyear period, there is room to make up the difference and China should endeavor to meet those commitments. But the status of the Phase One agreement as a framework for long-term trade relations remains an open question. Some observers would note that while it set quantitative targets for imports, the mechanism for achieving them was through government mandates, which strengthened the hand of the state, but did little new to bring about structural, market-based opening.

How the United States will address trade issues with China points to both bilateral and multilateral paths. There is a growing belief in United States and wider policy circles that China is not in compliance with key commitments it made on joining the WTO - specifically that courts would be independent in their judgments, that investors would not be required to transfer their technology, that MFN and national treatment would be afforded on a non-discriminatory basis to foreign rights holders of intellectual property, and that state-owned enterprises would make decisions on commercial terms without government guidance or direction. While China may not be out of technical compliance, many also believe that subsidies to state-owned enterprises and their subsequent transmission through the production value chain are non-compliant with the WTO's guiding market principles.

It was widely believed at the time of China's accession to the WTO, that its economy would evolve in a direction increasingly compatible with those market principles, and for many years there was reason to believe that was occurring. The recent strengthening of China's state sector, however, and the prominent role played by government direction and subsidies has challenged that belief. The increased influence being exerted by the central government over China's private technology companies has further deepened concerns regarding the independence of private 
companies and the role of the state. This opens another field of debate that will particularly impact multinationals, namely how disputes should be resolved within the WTO if China is ultimately considered to be less than a market economy or out of compliance with its obligations. This is not an issue of whether China is entitled to its own system, but rather how it interacts with the United States and other market economies in a rules-based global order. Changes at the WTO either through cases filed or through structural reforms could significantly impact multinational operations in China through both trade or investment.

Investment has emerged as an issue parallel to trade and is closely entwined with it. Two-way venture and Foreign Direct Investment (FDI) between the United States and China peaked in 2016 and has sharply declined since then. The drop in China's investment in the United States is attributable, in part, to capital controls imposed by the central government that are unconnected to political concerns and particularly impacted investment in fixed or non-strategic assets such as real estate. Some part can also be attributed to a cooling of venture activity within China. A significant part of the drop, however, reflects a cooling of the domestic climate for Chinese venture investment, occasioned by the lead up to and passage of the Foreign Investment Review and Modernization Act (FIRRMA) in September 2018. That act increased the authority of CFIUS (the Committee on Foreign Investment in the United States) to review inbound foreign investment for national security concerns. While not specific to China, CFIUS' caseload is made up primarily of Chinese transactions.

Its new authority has allowed CFIUS, with expanded staff resources, to review not only major acquisitions but also the purchase of minority stakes in smaller companies producing important technologies, where the transaction would enable an investor to participate in important decisions or gain access to the technology. The list of technologies considered sensitive is long and includes many of the most important emerging fields. Transactions that would give the investor access to significant amounts of sensitive personal information are subject to particular scrutiny. CFIUS also has the power to unwind deals that have already been concluded. In practice, its framework doesn't fully prevent Chinese investment, since greenfield investments from China or other countries fall outside its jurisdiction and legal mechanisms are available to enable otherwise sensitive transactions to go forward by separating the investing party from decision-making. Nevertheless, the breadth of CFIUS review and the likelihood of more intensive scrutiny can be enough to discourage investment from China and is significantly impacting venture flows, particularly to Silicon Valley.

This includes investment from both smaller Chinese VCs and large Chinese companies such as Baidu, Tencent and Alibaba that have been particularly active in both investment and acquisitions in the Valley. The weakening of what had been a growing investment bridge between China and Silicon Valley reflects increased concern by the US government over the potential leakage of technologies considered strategic from the perspective of either defense or global competition. In contrast to the concern over Chinese investment with comparable investment from other countries such as Japan, the issue for the US government is less one of economic competition in the traditional sense than of the potential linkage of particular investments to 
the strategic and military goals of China's government. Underlying that is the recognition that under Chinese law and policy private companies are ultimately answerable to the state and are required to cooperate with it. Therefore, where a transaction with a Japanese or German company might raise competitive issues, a transaction with a Chinese company has implications that may touch on broader policies. Efforts by the central government to extend Party influence deeper into the corporate structures of private Chinese companies have done nothing to dispel those concerns.

\section{Changing Approaches from Trump to Biden}

The US approach to how it manages relations with China has moved in a more positive direction under the Biden Administration than under its predecessor and will be more constructive on the whole. The aggressive rhetorical edge that characterized the Trump Administration has diminished and Washington will seek out areas where cooperation with China is possible, including climate change, nuclear proliferation and possibly global health. Economic decoupling, a goal explicitly embraced by the Trump Administration, will fade from the lexicon as the nature of the deep interconnections between the United States and Chinese economies is recognized. This shift has been welcomed by both multinationals and smaller companies in the San Francisco/Silicon Valley Bay Area and California as being indicative of a more pragmatic view toward China that will enable more stability and certainty for investors. The region enjoys strong historic and cultural ties with China and in recent decades its companies have been prominent partners in China's economic development. At the sub-national level, state, regional and city organizations continue to actively support stronger business ties. The Biden Administration's more balanced approach to China will enable them to sustain historic channels of economic cooperation and pursue new opportunities even as national debates continue.

Still, it was clear during the 2020 election and in the Biden Administration's early months that the Trump Administration's policies toward China would not be rejected outright and that many would be retained. Senior appointees including Secretary of State Tony Blinken have expressed the view that the United States and China are global competitors and that differences on a range of non-economic issues such as Xinjiang and the future of Hong Kong will not go away. Internal reviews of China policy at other US agencies suggest that while the tone will change there will be more continuity than discontinuity with Trump policies. This reflects a broad bipartisan agreement in Washington on the nature of the challenge that China poses and the need to address it.

The current business climate raises particular issues for US internet and online content companies, which are predominantly based in the San Francisco/Silicon Valley Bay Area. This comes as greater control is being imposed on the internet in China. One example is the requirement by the Cyberspace Administration in late 2020 that Apple remove a large number of gaming apps from its Apple Store, impacting both Chinese and overseas app developers. Trip Advisor, a non-gaming app, was also 
required to be removed. By one report Apple had 272,000 games in its China App Store in 2019, 94,000 of which were removed in 2020, a number far higher than the 25,000 taken down the previous year. Apple states that it complies with local laws but in addition to limiting market opportunity restrictions of this nature place Apple and companies like it in an increasingly difficult position with both users and critics outside China where access to apps and information don't face similar barriers. A similar issue may confront Silicon Valley internet companies in Hong Kong if the new security law there requires them to share user data with the government.

Another variable affecting multinationals will be the degree to which the United States and Chinese economies and technology systems will remain linked. Under the Trump Administration, pressure grew to decouple the two systems. That outcome would reduce US vulnerability to disruption in key technology supply chains. The Trump Administration's actions to restrict access by Chinese companies to key products such as advanced semiconductors, however, also served to accelerate China's efforts to reduce its dependence on foreign technologies. It is unlikely that the Biden administration will embrace decoupling as a strategic goal. This stems from a practical recognition that the United States and Chinese economies are intertwined and that is neither desirable nor possible to fully separate the two.

As a sign that future US technology policy will be more nuanced, in January 2021 the Biden Administration suspended implementation of a Trump Administration order that would have prevented Americans from investing in companies believed to have ties to China's military, an edict that caught up companies such as Xiaomi and China Unicom whose ties to China's military were questionable. And despite its continuing focus on the security issues posed by the presence of scientific researchers from China on US university campuses, in July 2021 the Justice Department dropped its legal cases against five visiting academics who were accused of not disclosing their ties to China's military.

Like its predecessor, however, the Biden Administration will devote significant attention to the concept of secure global supply chains for key products and technologies, which points to a further separation of the countries' technology systems over time. It is noteworthy that in February 2021, in one of its first actions, the administration issued an executive order establishing a 100-day review of steps needed to ensure secure, resilient supply chains. While much of that focus will be on domestic investment and production, concern with international vulnerabilities in fields such as pharmaceuticals, semiconductors and ICT lie in the background and the process will look to "areas where civilian supply chains are dependent on competitor nations." For some multinationals and other companies producing in China, this suggests a China-plus strategy, where production remains in China, but dependence on a single source of supply is reduced by spreading production to one or more other countries. Southeast Asia will likely be the prime beneficiary, but India and Mexico could also see growing investment flows. 


\section{Executive Views of China's Business Environment}

A February 2021 poll of global technology executives conducted by the Brookings Institution found that most respondents expect the United States and Chinese governments to continue a range of policies that will lead to greater decoupling, causing the global technology industry to increasingly bifurcate into two spheres; under a tenth believe that in the next ten years the technology industry will be global and open. They also believe that China will continue its industrial policy model of subsidizing national champions in technology sectors and tilting procurement rules toward local companies. They do not want the United States to follow a similar path of subsidization and politically driven procurement but recommend instead that it maintain its openness to foreign capital and technology while sustaining its more activist policies to limit the transfer of key US technologies abroad.

Respondents to the poll came primarily from the high-tech hardware, IT services, semiconductor and internet sectors, as well as the financial and professional services, telecommunications, and biotech and healthcare industries. Approximately half were from companies headquartered in China and the rest from US, Japanese, Taiwanese, Korean, UK and German companies. In answer to specific questions, $85 \%$ of respondents believed that despite calls for fair access for American firms to the Chinese market, the Chinese government will increasingly close its tech markets to foreign firms, providing access only to foreign companies with joint ventures or local partners with the possible exception of foreign companies with special, leading technologies. Sixty-three percent believed that while the PRC's technology market will become more open legally, there will continue to be an unfair playing field for foreign technology companies. Two-thirds expect Beijing to use heavy subsidies to support national champions and achieve self-reliance. Only one in ten expect the Chinese government to pursue deregulation initiatives.

Regarding the United States, $62 \%$ of respondents to the poll believe the US government will increase restrictions on high-tech exports to China. They do not, however, expect the global distribution of the technology industry or the mutual dependence of the United States and Chinese technology industries to significantly change, with Chinese companies showing continuing strength in developing system or solutionlevel technological applications, and the United States retaining its strength in core components such as semiconductors and software, and in upstream advanced manufacturing and design industries such as leading-edge foundries and semiconductor manufacturing equipment and materials. Most believe, for example, that in the next five years China will be home to a top-three global electrical vehicle company and a top-three global cloud services provider, but few believe that China will produce a top three GPU, CPU or operating systems provider, or that it will successfully build a top-three global player in leading semiconductor tools.

Despite the political headwinds, these views suggest a reasonable degree of continuity in US-China business relations, at least for the near term. The respondents believe that Chinese companies will continue to work pragmatically with American suppliers. While future US government policies will impact their path, the great 
majority (95\%) expect Chinese companies to welcome back American suppliers to which they are currently denied access but expect those companies will have a back-up plan to replace American suppliers if and when there is a comparable Chinese-sourced product or technology. This means that the success of most American companies will turn more on their ability to stay ahead of Chinese competitors in technology and supplier value (including price, quality and time to market) than on government policies. This would be consistent with the view of Chinese companies participating in the poll that American companies will continue to dominate global technology markets in the next 10 years, and with a parallel belief among many that Chinese government efforts to achieve self-reliance will be uneven across different sectors of the economy and in some cases ineffective.

US respondents to the poll also recognize their dependence on China for both customers and revenue and have signaled their desire to maintain their presence in China, even as they comply with US laws and export controls. Four out of five say they will continue to vigorously compete in China, with more than half saying they will focus on localizing their operations. A substantial minority, however-one in five-say they plan to leave the Chinese market. Leaders in both Chinese and US companies want the United States to strengthen its commitment to globalization and avoid the Chinese path of subsidies or industrial support. Interestingly, fewer than $20 \%$ believe that US policy should take a hands-off "let the market decide" approach to addressing US-China business issues, with half being supportive of US cooperation with allies to manage China's access to critical technologies. Multinationals with China-headquartered companies are more likely to suggest the "hands-off" approach but significantly were just as supportive as their non-China headquartered counterparts of tighter restrictions on technology transfer.

One major takeaway from these views is that while multinationals will continue to compete on a global basis they may not operate in the same way in the United States and China or their respective ecosystems but will customize their activity for the United States and Chinese spheres. That will impact decisions regarding where to locate intellectual property and core R\&D. Not wishing to exit either market, they will need to absorb the growing cost and complexity in their operations.

\section{Looking Forward}

AmCham Shanghai's 2020 China's Business Report indicated that, despite the trade war, more than $78 \%$ of the 346 companies responding to its survey were profitable, slightly ahead of recent years, and $32 \%$ projected profits greater than in 2019 . The importance of China's consumer markets should continue to grow for multinationals, as China's strong recovery from the COVID-19 crisis has produced surging demand for products ranging from cosmetics to automobiles. For many overseas companies, strong revenues in China have helped offset weak revenue in economies where recovery from the pandemic has been slower. In 2020, China was the only major 
economy to experience positive growth $(2 \%)$; reflecting this, while global FDI fell in 2020, FDI in China grew, reflecting expectations of continued Chinese growth.

Chinese government policies will inevitably impact the degree to which overseas multinationals and other companies will participate in that growth. Directions announced at the Fifth Plenum in 2020 provide mixed signals. An emphasis on the domestic market under "dual circulation" suggests expanding market opportunities. The strengthening role of the state in economic decision-making also suggests, however, that much of that activity will be linked to state goals, further diluting the role of market forces. Likewise, the emphasis on technological self-reliance in the Fifth Plenum and the 14th Five Year Plan may cause overseas partners to question their long-term welcome and competitiveness in China.

Corporate views in the San Francisco/Silicon Valley Bay Area follow similar lines, but with a perspective linked to the region's status as the major United States and global technology center. Internet companies such as Google, Facebook and Twitter are not participating in China's market because they are unable to operate on the same open basis in China as they do in other global economies. While the reasons for this are well understood, current policies shield China's internet sector from competition, restrict consumer options, and by creating a protected domestic bubble, isolate Chinese companies from broader global markets.

Other movements point to a selective opening to foreign multinationals that will benefit Bay Area and Silicon Valley companies. The success in China's automotive market of Tesla, which produces vehicles in Shanghai as a 100\% foreign-owned producer of electrical vehicles, suggests that where foreign investment aligns with government priorities, overseas companies can prosper. Tesla currently leads all producers of EVs in domestic sales, ahead of BYD, Guangzhou Auto, Beijing Auto and other major companies, and the company has announced that it will soon begin exporting China-produced vehicles to Europe. Likewise, after an extended delay, Visa has been given access to China's payments market, reflecting earlier announcements of financial market liberalization and commitments made in the US-China Phase One trade deal.

Several directional shifts in US policy would benefit US-China business and enable more investment and trade. One is that US government framework for reviewing trade in technology risks being overly broad. The uncertainty that results inhibits trade and investment but with questionable benefits to the US economy or security. While a strategic process of this kind is clearly necessary, a more transparent and selective approach to those controls would be welcomed by many US businesses. Likewise, unilateral controls on technology transfer, when layered on overly broad definitions, can be counterproductive. Where possible, those processes should be targeted and multilateral and allow non-impacted business activity to develop with less uncertainty.

China also has an opportunity to create new space for trade and investment. The term "opening up" is used often by officials, but without specificity regarding exact measures or their timing. More transparency is needed to inspire confidence. Here, the burden will be on China to open previously closed sectors in a clear and timely manner. The removal of equity caps and joint venture requirements in a broader range 
of sectors is a particular area where more progress would be welcome and China's opening up would take on greater meaning.

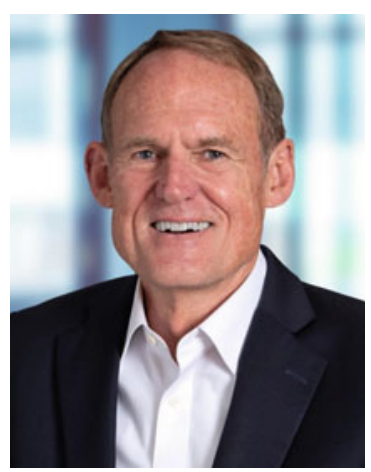

Sean Randolph is Senior Director of the Bay Area Council Economic Institute, where he served as President and CEO from 1998 to 2015 and manages its science affiliate the Bay Area Science and Innovation Consortium (BASIC). Randolph previously served as Director of International Trade for the State of California, and prior to that as International DirectorGeneral of the Pacific Basin Economic Council (PBEC), a 1,000 member Asia-Pacific business organization. His professional career includes extensive experience in the US government, where he served on Congressional staffs, on the White House staff, and in senior positions at the Departments of State and Energy. Dr. Randolph holds a JD from the Georgetown University Law Center, a Ph.D. from the Fletcher School of Law and Diplomacy (Tufts and Harvard Universities), a B.S.F.S. from Georgetown's School of Foreign Service, and studied at the London School of Economics.

Open Access This chapter is licensed under the terms of the Creative Commons AttributionNonCommercial-NoDerivatives 4.0 International License (http://creativecommons.org/licenses/bync-nd/4.0/), which permits any noncommercial use, sharing, distribution and reproduction in any medium or format, as long as you give appropriate credit to the original author(s) and the source, provide a link to the Creative Commons license and indicate if you modified the licensed material. You do not have permission under this license to share adapted material derived from this chapter or parts of it.

The images or other third party material in this chapter are included in the chapter's Creative Commons license, unless indicated otherwise in a credit line to the material. If material is not included in the chapter's Creative Commons license and your intended use is not permitted by statutory regulation or exceeds the permitted use, you will need to obtain permission directly from the copyright holder.

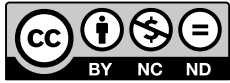

